$\begin{array}{ccc}\text { JURNAL BIOTERDIDIK: WAHANA EKSPRESI ILMIAH } & \begin{array}{c}\text { e-ISSN: } \\ 2621-5594 \\ \text { p-ISSN: } \\ \hline \text { Jurnal Bioterdidiik }\end{array} \\ \begin{array}{c}\text { Vol. 8 No. 3, Desember 2020, page. 76-83 } \\ \text { http://jurnal.fkip.unila.ac.id/index.php/JBT/ }\end{array} & 2302-1276 \\ \text { doi: } 10.23960 / \text { jbt.v8.i3.09 } & \end{array}$

\title{
Analisis Pola Hubungan Antara Gaya Belajar, Karakter dan Multiple Intelligences Mahasiswa Pada Pembelajaran Biologi Terintegrasi Fenomena Coronavirus-19
}

\author{
Noor Hujjatusnaini*, Meliyani, Yuliandari, Iis Yulianti, Noor Yulia Sulistiowati, \\ Nur Istiqomah \\ Tadris Biologi. Fakultas Tarbiyah dan Ilmu Keguruan. Institut Agama Islam Palangka Raya. \\ Jalan Obos G., Palangka Raya, Kalimantan Tengah 74874, Indonesia; \\ *email: noor.hujjatusnaini@iain-palangkaraya.ac.id.
}

\begin{abstract}
Analysis of Relationship Patterns of Student Learning Styles, Characters and Multiple Intelligences in Biology Learning Integrated Coronavirus-19 Phenomenon. This research is a qualitative descriptive study that aims to determine the relationship patterns of learning styles, characters and multiple intelligences of students in biology learning integrated of the coronavirus-19 phenomenon. The research method is a crosssectional survey method. The research sample was 40 students in the Biology Education Study Program of IAIN Palangka Raya. The results of the study that the learning styles, character, and multiple intelligences possessed by students showed a strong and mutually influencing relationship. Students with linguistic verbal intelligence and mathematical logical intelligence have higher moral-knowing, while students with intrapersonal, visual, and musical intelligence have stronger moral-feeling. In contrast, students with naturalist, interpersonal, and kinesthetic intelligence have the moral-action with the strongest personality values.
\end{abstract}

Keywords: character education, learning style, moral dilemma, multiple intelligences

\begin{abstract}
Abstrak: Analisis Pola Hubungan Antara Gaya Belajar, Karakter dan Multiple Intelligences Mahasiswa Pada Pembelajaran Biologi Terintegrasi Fenomena Coronavirus -19. Penelitian ini merupakan penelitian deskriptif kualitatif dengan metode survey crossectional pada 40 mahasiswa di Program Studi Tadris Biologi IAIN Palangka Raya. Instrumen karakter siswa tersebut dinamakan tes dilema moral dengan mengangkat fenomena wabah Covid-19. Hasil penelitian bahwa gaya belajar, karakter, dan multiple intelligences yang dimiliki mahasiswa menunjukkan hubungan yang kuat dan saling mempengaruhi. Mahasiswa yang memiliki multiple intelligences tinggi memiliki kecenderungan menggunakan gaya belajar gabungan. Mahasiswa dengan kecerdasasan verbal linguistik dan logis matematis memiliki moral-knowing yang lebih tinggi, sedangkan mahasiswa dengan kecerdasan intrapersonal, visual, dan musikal memiliki moral-feeling lebih kuat. Sebaliknya, mahasiswa dengan kecerdasan naturalis, interpersonal, dan kinestetis memiliki moral-action dengan nilai personality paling kuat
\end{abstract}

Kata kunci: dilema moral, gaya belajar, multiple intelligences, pendidikan karakter 


\section{PENDAHULUAN}

Pada hakikatnya setiap anak itu memiliki kecerdasan dengan tingkatan yang berbeda-beda, yang dikenal dengan istilah kecerdasan majemuk atau kecerdasan ganda (multiple intelligences). Perbedaan tersebut tampak pada tingkat dan indikator kecerdasannya (Musfiroh, 2015). Tingkat kecerdasan yang dimiliki mahasiswa dipengaruhi oleh beragam faktor, salah satunya adalah rangsangan terhadap kecerdasan sejak usia dini. Perbedaan kecerdasan yang dimiliki mahasiswa menuntut dosen untuk mampu mendeteksi eksistensi kecerdasan personality dengan cara pengamatan perilaku, minat, kecenderungan, dan respon mahasiswa terhadap stimulus yang diberikan dalam proses pendidikan dan pembelajaran (Larson, 2001).

Kecerdasan dan karakter personality mahasiswa dapat dibentuk melalui pendidikan, sebagaimana tertuang dalam UU No.29 Tahun 2003. Berdasarkan hasil obeservasi dan wawancara terhadap mahasiswa di Program Studi Tadris Biologi IAIN Palangka Raya, bahwa proses pembelajaran yang cenderung terbatas transfer ilmu pengetahuan masih fokus pada perolehan kognitif. Pengembangan karakter dan kecerdasan tidak dicapai secara komprehensif yang menjadi satu kesatuan. Untuk mencapai pembelajaran karakter dan kecerdasan secara bersamaan, diperlukan pembelajaran yang variatif, sesuai dengan bakat dan minat yang dimiliki mahasiswa (Sulaiman, 2011; Armstrong, 2013). Multiple intelligences yang tinggi merupakan pembelajaran yang menekankan pada kekukatan verbal, visual, dan interpersonal, sehingga karakter demokratif dan komunikatif akan terbangun lebih optimal dibandingkan yang lainnya (Yaghoob, 2016). Hal inilah yang memperkuat fakta bahwa komunikasi demokratif dan komunikatif merupakan kecerdasan yang didasari oleh kecerdasan verbal linguistik, sedangkan karakter demokratif didasari oleh kecerdasan verbal interpersonal dan intrapersonal (Armstrong, 2002; Larson, 2001).

Multiple intelligences yang rendah merupakan pembelajaran yang menekankan pada naturalis, matematis, logis, musilkal, dan kinestetis. Karakter berpikir logis menggambarkan rendahnya kepekaan terhadap fenomena sekitar, rendahnya kecerdasan naturalis, musikal, dan logis matematis (Armstrong, 2003). Multiple intelligences dan karakter merupakan bagian dari pendidikan, sebagai penentu nilai personality (Hosseini, 2004; Hervin, 2016). Karakter tidak hanya sebagai pelengkap kompetensi, tetapi lebih sebagai dasar jiwa (ruh) (Armstrong, 2013). Oleh karena itu, pendidikan karakter hendaknya tidak hanya sebagai pelengkap kompetensi semata, tetapi lebih sebagai dasar jiwa atau ruh (Ahmed, 2012). Hal inilah yang menjadi dasar pentingnya mengkaji pola korelasi multiple intelligences dengan karakter mahasiswa, terkait wabah Covid-19.

Wabah Covid-19 merupakan fenomena alam yang bersifat pandemic bagi seluruh dunia, baik Asia maupun Eropa. WHO melaporkan Indonesia tercatat sebagai negara yang memiliki angka kematian tertinggi di ASEAN yaitu sebesar 13,11\%, sedangkan Italia melaporkan tingkat kematian akibat Covid-19 sebesar 15\%, yang jauh lebih besar dari rata-rata global kematian (3,4\%) (Yustina, 2020). Menghadapi pandemi Covid-19 pemerintah di seluruh dunia memberlakukan "social distancing, termasuk Indonesia. Hal ini disebabkan Covid-19 merupakan wabah yang masih belum bisa dipetakan, sehingga "social distancing" diharapkan dapat menekan angka penularan infeksi tersebut. Pembelakuan social distancing meliputi seluruh layanan masyarakat, transportasi umum, perkumpulan dalam skala besar, pembatasan interkasi di pasar umum, dan juga sekolah serta sarana pendidikan lainnya. Sosial distancing berangkat dari self distancing, dimana upaya menjaga diri dengan orang lain. Yu-Tao (2020) menyatakan bahwa ketika seseorang telah terpapar virus, maka perlu dilakukan self isolasion ataupun self karantina, sehingga menjaga interaksi dalam satu komunitas. Langkah "local lockdown" 
diberlakukan pada suatu area jika telah terindikasi terinfeksi. Huang (2020) menegaskan wabah Covid-19 merupakan fenomena pandemik yang menuntut keterlibatan cerdas dan proaktif seluruh masyarakat, termasuk mahasiswa sebagai bagian dari masyarakat akademik. Masyarakat diharapkan tidak hanya mengerti tentang wabah, tetapi lebih dituntut terlibat cerdas dan aktif secara personal, yang termanifestasi dalam perilaku dan tindakan. Periaku dan tindakan seseorang merupakan bagian dari karakter dan multiple intelligences (Armstrong, 2003; Laidra, 2007). Tujuan studi ini untuk mengetahui pola hubungan gaya belajar, dengan karakter personal yang dilihat berdasarkan multiple intelligences yang dimiliki mahasiswa terhadap wabah Covid-19 yang diintegrasikan dalam pembelajaran.

\section{METODE}

Penelitian ini merupakan penelitian deskriptif kualitatif. Karakter mahasiswa ditentukan berdasarkan respon mahasiswa terhadap fenomena dan permasalahan yang terjadi di sekitar. Penelitian didesain dengan melakukan pengelompokkan mahasiswa berdasarkan tingkat kecerdasan yang dimilikinya. Pengelompokkan tingkat kecerdasan diperoleh dari hasil identifikasi multiple intelligences mahasiswa melalui angket, yang diadopsi dari tes identifikasi kecerdasan menggunakan model kecerdasan Howard Gardner yang dikembangkan oleh Thomas Armstrong (Hosseini, 2004).

Teknik pengumpulan data dilakukan menggunakan angket dengan berisi 80 pernyataan yang mewakili masing-masing tingkat kecerdasan. Angket diberikan pada 40 orang mahasiswa yang menempuh matakuliah Mikrobiologi dengan tingkat kecerdasan yang berbeda. Selanjutnya diberikan tes untuk mengukur pengetahuan, perasaan, dan tindakan moral personality mahasiswa, dengan menggunakan instrumen karakter. Instrumen karakter siswa tersebut dinamakan tes dilema moral dengan mengangkat fenomena alam yang terjadi, yaitu terkait bencana asap dan kebakaran hutan. Permasalahan yang dimunculkan dirancang sedemikian rupa, menciptakan pemikiran dan perasaan dilematis personality mahasiswa. Mahasiswa diarahkan untuk dapat mengungkapkan apa yang mereka pikirkan, rasakan, dan rencana tindakan yang akan dilakukan terhadap masalah yang dimunculkan. Data hasil penelitian merupakan data deskripsi kualitatif terkait masalah yang disajikan, yang kemudian dianalisis berdasarkan komposisi karakter.

\section{HASIL DAN PEMBAHASAN}

Data hasil penelitian menunjukkan mahasiswa dengan tingkat kecerdasan yang hampir setara menunjukkan gaya belajar dan karakter yang hampir serupa, sehingga tampak suatu pola korelasi antara gaya belajar dan tingkat kecerdasan terhadap karakter yang dimiliki. Hasil penelitian menemukan 2 tipe gaya belajar yang ditunjukkan mahasiswa dalam pembelajaran, yaitu kecenderungan menggunakan satu tipe gaya belajar dan menggunakan gaya belajar gabungan. sebagaimana dijabarkan dalam Tabel 1 .

Tabel 1 menunjukkan bahwa gaya belajar mahasiswa Tadris Biologi IAIN Palangka Raya didominasi oleh gaya visual (30\%) dan gaya auditorial (25\%). Perbandingan antara gaya belajar tunggal (visual 30\%, audotorial 25\%, 17.5\%) lebih dominan muncul dibandingkan gaya belajar gabungan (visual audotorial $12.5 \%$, visual kinestetik $10 \%$, auditorial kinestetik 5\%). Gaya belajar yang dimiliki merupakan modal dasar pebelajar dalam menerima materi pembelajaran. Gaya belajar yang ditemukan dikaji lebih keterkaitan dengan multiple intelligences dan karakter yang dimiliki 
mahasiswa terhadap permasalahan kontekstual tentang pandemi covid-19 saat ini yang dimunculkan dalam materi pembelajaran, dengan tujuan untuk mengetahui eksistensi kecerdasan personality mahasiswa. Pola karakter mahasiswa pada kemampuan multiple intelligences tinggi ditunjukkan pada Gambar 1.

Tabel 1 Frekuensi Gaya Belajar Mahasiswa

\begin{tabular}{|c|c|c|c|}
\hline \multirow{7}{*}{ 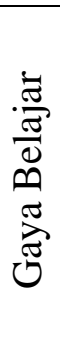 } & Gaya Belajar & Frekuensi & $\%$ \\
\hline & Visual & 12 & 30 \\
\hline & Auditorial & 10 & 25 \\
\hline & Kinestetik & 7 & 17.5 \\
\hline & Visual Auditorial & 5 & 12.5 \\
\hline & Visual Kinestetik & 4 & 10 \\
\hline & Auditorial Kinestetik & 2 & 5 \\
\hline
\end{tabular}

Hasil penelitian pada Gambar 1 diperoleh gambaran bahwa mahasiswa dengan multiple intelligences tinggi mengutamakan perasaan moral $(66.67 \%)$ dan tindakan nyata (66.67\%) yang lebih tinggi dibandingkan pengetahuan yang dimiliki (53.33\%), ketika dihadapkan pada kasus yang dimunculkan dalam pembelajaran. Mahasiswa dengan kecerdasan visual-auditorial lebih mengutamakan perasaan $(66.67 \%)$ dibandingkan pengetahuan dan tindakan. Mahasiswa dengan kecerdasan interpersonal (66.67\%) lebih mengutamakan tindakan dibandingkan pengetahuan dan perasaan. Sebaliknya, mahasiswa dengan kecerdasan verbal linguistik lebih dominan menggunakan pengetahuan (53.33\%) yang dimiliki dibandingkan perasaan dan tindakan yang dilakukan.

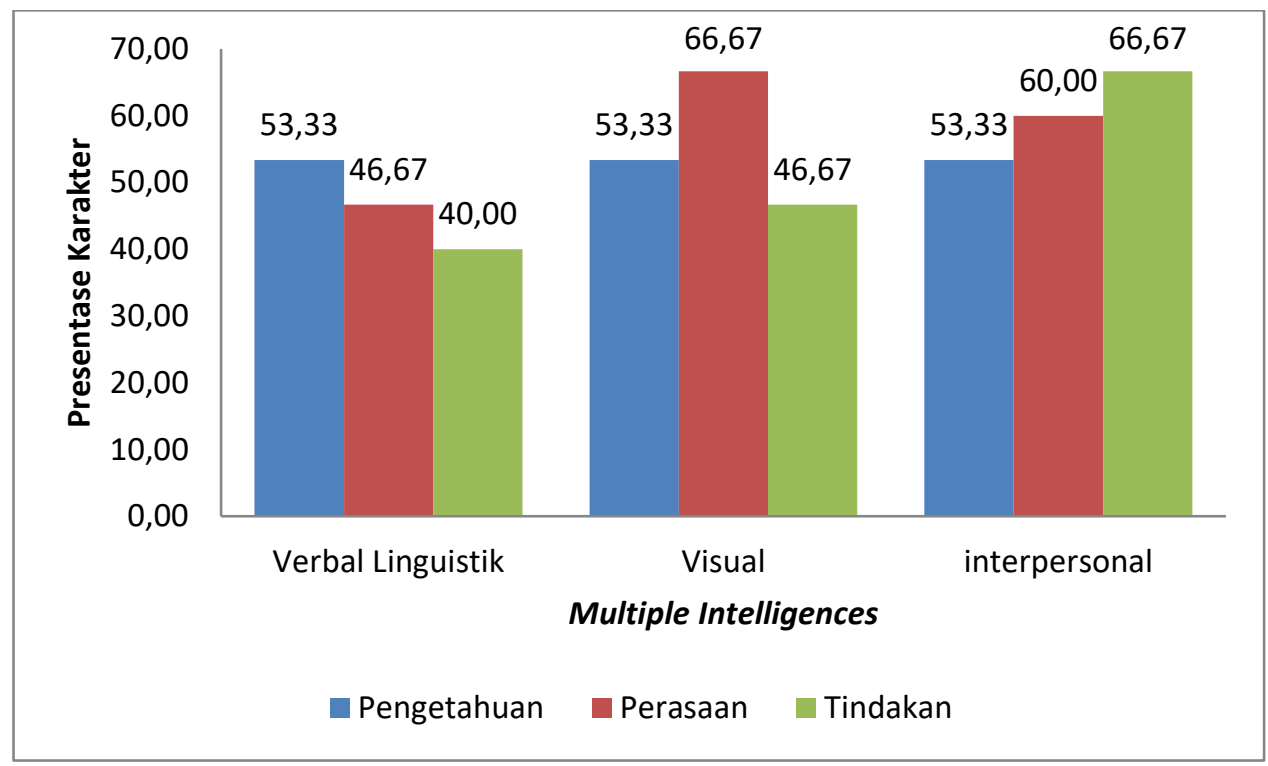

Gambar 1. Pola Karakter pada Kelompok Mahasiswa dengan Multiple Intelligences Tinggi

Pola karakter mahasiswa dengan multiple intelligences rendah disajikan pada Gambar 2. Pola karakter yang ditunjukkan pada Gambar 2 tampak bahwa mahasiswa dengan multiple intelligences rendah mengutamakan tindakan nyata $(73.33 \%)$ dibandingkan pengetahuan $(66.67 \%)$ dan perasaan $(66.67 \%)$. Pembelajaran yang 
dihadapkan pada permasalahan kontekstual terkait wabah pandemi covid-19 pada mata kuliah mikrobiologi dasar memunculkan kekuatan pola karakter mahasiswa pada tingkat kecerdasan yang dimiliki. Mahasiswa dengan kecerdasan kinestetis (73.33\%) dan naturalis $(66.67 \%)$ lebih mengutamakan tindakan dibandingkan pengetahuan dan perasaan, sedangkan mahasiswa dengan kecerdasan intrapersonal $(66.67 \%)$ dan musikal (66.67\%) lebih mengutamakan persaan dibandingkan pengetahuan dan tindakan. Sebaliknya, mahasiswa dengan kecerdasan logis lebih dominan menggunakan pengetahuan (66.67\%) secara logis yang dimiliki dibandingkan perasaan dan tindakan yang dilakukan.

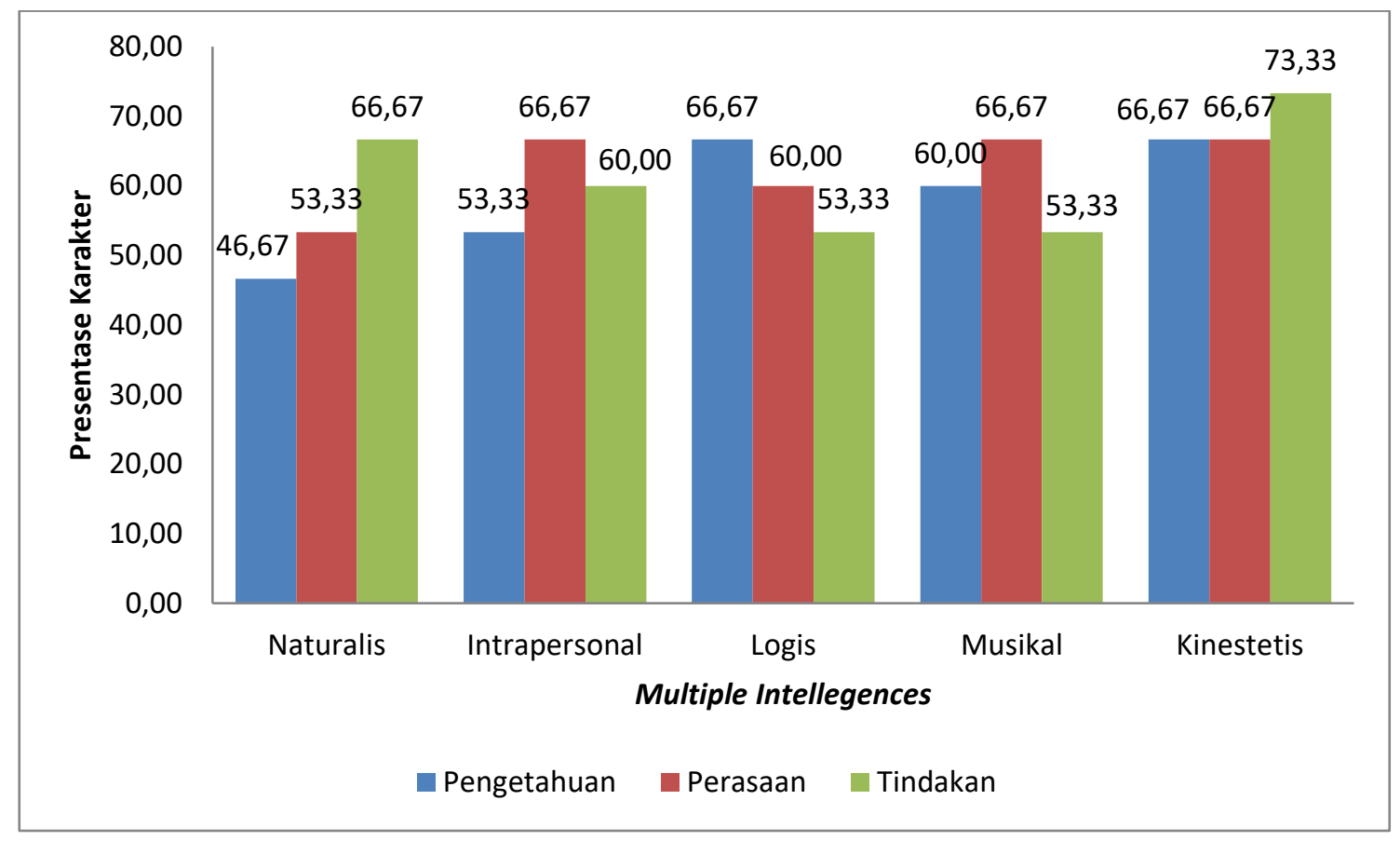

Gambar 2. Pola Karakter pada Kelompok Mahasiswa dengan Multiple Intelligences Rendah

Data hasil penelitian tersebut di atas ditemukan gaya belajar mahasiswa Tadris Biologi IAIN Palangka Raya, dengan kecenderungan menggunakan satu tipe gaya belajar, dan juga menggunakan gabungan gaya belajar. Pada dasarnya tipe gaya belajar ada 3 tipe dasar, seseorang pebelajar cenderung menggunakan salah satunya, dan ada pula yang menggunakan dalam bentuk gabungan dari beberapa gaya belajar. Penggabungan beberapa gaya belajar inilah yang dipahami sebagai kecerdasan majemuk (Thobroni \& Mustafa, 2011).

Gaya belajar merupakan variasi cara pebelajar dalam mengakumulasi dan mengasimilasi informasi dan pengetahuan yang diterimanya. Pebelajar yang memiliki multiple intelligences tinggi cenderung menggunakan lebih dari satu tipe gaya belajar (Tabel 1). Sejalan dengan data tersebut, bahwa gaya belajar yang variatif memiliki karakter yang lebih kuat pula (Gambar 1 dan 2). Hasil analisis menunjukkan gambaran bahwa mahasiswa dengan kecerdasan verbal linguistik dan juga logis matematis memiliki karakter pengetahuan lebih tinggi dibanding intelligences lainnya. Tetapi mahasiswa dengan karakter pengetahuan yang lebih tinggi secara verbal dan logis matematis tidak menjamin akan memiliki kemampuan merasakan dan mengimplementasikannya 
pengetahuan dan perasaannya dalam tindakan moral. Mahasiswa dengan kecerdasan visual, intrapersonal, dan musikal cenderung menekankan perasaan moralnya daripada kognitif dan merealisasikannya dalam tindakan. Sebaliknya, mahasiswa dengan kecerdasan interpersonal, naturalis, dan kinestetik memiliki kecenderungan memberikan respon dalam bentuk tindakan nyata terhadap masalah yang terjadi.

Kecerdasan linguistik merupakan kemampuan verbal seseorang dalam menggunakan kata-kata secara efektif, baik secara lisan maupun tulisan (Laidra, 2007). Mahasiswa yang memiliki kecerdasan verbal linguistik memiliki kecenderungan mengekspresikan perasaan yang dimiliki dalam bentuk kata-kata, sehingga ekspresi pengetahuan lebih dominan dibandingkan tindakan (Yaghoob, 2016). Demikian pula dengan kecerdasan logis-matematis, yang lebih menekankan pada pola-pola numerik, dan mengolah pengetahuan yang dimiliki dalam jangka waktu yang lebih panjang (Gulap, 2014). Kecerdasan logis-matematis memiliki kemahiran berlogika, mampu memecahkan masalah secara logis, serta lebih cepat menganalisis sebab dan akibat dari suatu permasalahan (Susanna \& Kam, 2006). Akan tetapi, data penelitian ini menunjukkan bahwa kelompok mahasiswa yang memiliki kecerdasan logis-matematis lebih mengedepankan perasaan daripada tindakan nyata.

Kecerdasan visual merupakan kemampuan visualisasi ide dan pemikiran yang dimiliki dalam bentuk sesuatu yang lebih konkret (Laidra, 2007; Yaghoob \& Hossein, 2016). Interpretasi karakter mahasiswa dalam penelitian ini lebih mengedepankan perasaan moral dibandingkan pengetahuan dan tindakan nyata. Demikian pula halnya dengan kecerdasan intrapersonal dan musikal. Kecerdasan intrapersonal merupakan kemampuan bertindak secara adaptif berdasarkan pengetahuan yang dimiliki, sedangkan kecerdasan musikal merupakan kemampuan dalam menanggapi pesan dan informasi (irama) di sekitar lebih seksama, yang kemudian mengekspresikannya dengan penuh perasaan (Yaghoob, 2016). Sejalan dengan data yang diperoleh dalam penelitian ini bahwa kecerdasan intrapersonal dan kecerdasan musikal mahasiswa lebih ekspresif pada perasaan dibandingkan pengetahuan dan tindakannya.

Kecerdasan interpersonal merupakan untuk memahami setiap gejala dan perbedaan yang ada di lingkungannya (Laidra, 2007). Kecerdasan naturalis merupakan kepekaan seseorang dalam menangkap setiap fenomena alam. Kecerdasan kinestetik merupakan kemampuan seseorang dalam mengekspresikan ide dan perasaannya dalam bentuk hasil cipta dan tindakan (Yaghoob, 2016). Sejalan dengan data penelitian menunjukkan mahasiswa yang memiliki kecerdasan interpersonal, naturalis, dan kinestetik memberikan respon lebih peka terhadap fenomena kasus yang disajikan. Seseorang dengan kecerdasan kinestetik akan memiliki kemampuan lebih maksimal ketika diberikan kesempatan lebih leluasa, dan membutuhkan stimulus lebih spesifik untuk memperoleh karakter personality yang lebih baik (Gulap, 2014; Ayu, 2018).

Meskipun data hasil analisis penelitian menunjukkan nilai yang lebih tinggi pada karakter personality tertentu, tetapi tidak dapat disimpulkan lebih rendah pada karakter lainnya. Interpretasi data dalam penelitian ini lebih menekankan bahwa dalam pembelajaran akan lebih optimal jika pengembangan karakter dan kecerdasan tidak dilakukan secara parsial, tetapi harus dicapai secara komprehensif yang menjadi satu kesatuan. Korelasi antara gaya belajar dan karakter yang dimiliki mahasiswa dan multiple intelligences terhadap permasalahan yang dimunculkan melalui pembelajaran diharapkan dapat terwujud dalam bentuk sikap dan tindakan nyata personal yang lebih konkret, tidak hanya berhenti pada ranah pengetahuan dan perasaan semata. 


\section{SIMPULAN}

Gaya belajar, karakter, dan multiple intelligences yang dimiliki mahasiswa dalam penelitian ini menunjukkan hubungan yang saling mempengaruhi. Proses pembelajaran yang diintegrasikan fakta dan fenomena kontekstual terkait pandemi Covid-19 menunjukkan gaya belajar dan karakter yang cukup variatif pada tingkat multiple intelligences yang dimiliki. Mahasiswa yang memiliki multiple intelligences tinggi memiliki kecenderungan menggunakan gaya belajar gabungan. Mahasiswa dengan kecerdasasan verbal linguistik dan logis matematis memiliki moral knowing yang lebih tinggi, sedangkan mahasiswa yang memiliki kecerdasan intrapersonal, visual, dan musikal memiliki moral feeling yang lebih dominan. Sebaliknya, mahasiswa yang memiliki kecerdasan naturalis, interpersonal, dan kinestetis memiliki moral action dengan nilai personality paling kuat.

\section{DAFTAR RUJUKAN}

Ahmed, A. (2012). The Relation Between Multiple Intelligences Theory and Methods of ELT. International Journal of Learning and Teaching, 4(2): 26-41.

Armstrong, T. (2002). Setiap Anak Cerdas: Panduan Membantu Anak Belajar dengan Memanfaatkan Multiple Intelligence-nya. Rina Buntaran. Jakarta: Gramedia Pustaka Utama.

Armstrong, T. (2003). Sekolah Para Juara. Terj.Yudhi Murtanto. Bandung: Kaifa.

Armstrong, T. (2013). Kecerdasan Multipel di dalam Kelas. Jakarta: PT Indeks.

Ayu Lestari, S. Sofendi, and Ismail Petrus. (2018). The correlations among undergraduate EFL students' reading habit, multiple intelligences, and writing mastery. Indonesian Journal of Applied Linguistics, 8(1): 110-120.

Gulap, Gomal, Islam, Faqir. (2014). Interrelation of Multiple Intelligences and their Correlation with Students'Academic Achievements: A Case Study of Southern Region, Khyber Pakhtunkhwa. FWU Journal of Social Sciences, 8(2): 59-64.

Haji, Nejhad, Baleghi. (2004). The comparison of teaching method on Gardner's multiple intelligences. Season Letter Of Mathematic Training, 20:1-19.

Hervin, A. (2016). The Relationship Between Multiple Intelligences and Reading Comprehension Achievement of The Eleventh Grade Students' of SMA Negeri 8 Palembang. Journal of English Literacy Education. 3(2).

Huang C, Wang Y, Li X, Ren L, Zhao J, Hu Y, et al. (2020). Clinical features of patients infected with novel coronavirus 2019 in Wuhan, China. 395: 497-506.

Laidra K, Pullmann H, Allik J (2007). Personality and intelligence as predictors of academic achievement: A cross-sectional study from elementary to secondary school. Personality and Individual Differences, 42(3):441-451.

Sulaiman T, Hassan A, Yi H. (2011). An analysis of teaching styles in primary and secondary school teachers based on the theory of multiple intelligences. J. Social Sci, 7(3):428-435.

Susanna, B and Lim, K. (2006). Correlations of Multiple Intelligences and Emotional Intelligence: A Closer Analysis of Theoretical Assumptions. The Korean Journal Of Thinking \& Problem Solving, 16(1), 53- 64.

Thobroni, M dan Arif, M. (2011). Belajar dan Pembelajaran. Yogyakarta: Ar- Ruzz Media.

World Health Organization. (2020) Statement on the second meeting of the International Health Regulations Emergency Committee regarding the outbreak of novel 
coronavirus (2019 $n \mathrm{CoV}$ ). (Online), (https://wwwwhoint/newsroom/detail/30-012020-statement-on-the-second-meeting-of-the-international-health-regulations(2005)-emergency-committee-regarding-the-outbreak-of-novel-coronavirus(2019-ncov).

Yaghoob, R and Hossein, Z. (2016). The correlation of multiple intelligences for the achievements of secondary students. Educational Research and Reviews, 11(4): 141-145.

Yaghoob, Hossein, Mahin, Fatemh. (2016). The Correlation between Gardner's Multiple Intelligences and the Problem-solving Styles and their Role in the Academic Performance Achievement of High School Students. European Online Journal of Natural and Social Sciences.5(1).

Yustina., W. Syafii., R. Vebrianto. (2020). The Effects of Blended Learning and ProjectBased Learning on Pre-Service Biology Teachers' Creative Thinking Through Online Learning in The Covid-19 Pandemic. Jurnal Pendidikan IPA Indonesia, 9 (3), 408-420.

Yu-Tao X,Yu-Jin, Yu-Wang, Qinge Z, Ling Z, Teris C. (2020). Tribute to health workers in China: A group of respectable population during the outbreak of the COVID-19. Int. J. Biol. Sci, 16(10): 1739-1740. 